\title{
THE ASSOCIATION BETWEEN DYSMENORHEA AND PHYSICAL ACTIVITY IN DIPLOMA III MIDWIVERY STUDENTS IN SORONG, WEST PAPUA, INDONESIA
}

\author{
Dyan Puji Lestari'), Yuni Subhi Isnaini'), Bahrah²) \\ 1)Diploma III Midwifery, Health Polytechnics Ministry of Health Sorong \\ 2) Health Polytechnics Ministry of Health Sorong
}

\begin{abstract}
Background: Dysmenorrhea is menstruation accompanied by severe pain and cramps. Adolescents who are experiencing menstrual pain or dysmenorrhea are unable to carry out activities and must rest. This study aimed to determine the association between dysmenorrhea and physical activity in the D-III Midwifery Study Program students of Manokwari.

Subjects and Methods: A cross-sectional study was conducted at the Diploma III Midwifery Study Program, Manokwari, West Papua, in April 2017. A total of 38 midwifery students were selected using a random sampling technique. The dependent variable was physical activity. The independent variable was dysmenorrhea. Data were collected using questionnaires and interviews. Data were analyzed using OR and chisquare test.
\end{abstract}

Results: As many as 79.0\% of midwifery students had moderate activities. Dysmenorrhea was not statistically associated with reduced physical activity in midwifery students $(\mathrm{OR}=0.36 ; 95 \% \mathrm{CI}=0.73$ to $1.81 ; \mathrm{p}=0.232)$.

Conclusion: Dysmenorrhea is not statistically associated with reduced physical activity in midwifery students.

Keywords: dysmenorrhea, physical activity, female students.

\section{Correspondence:}

Dyan Puji Lestari. Diploma III Midwifery, Health Polytechnics Ministry of Health Sorong. Slamet Riyadi Street, Upper Ambon Village, Manokwari, West Papua. Email: dyanlestari56@gmail.com. Mobile: +6281248194297. 